\title{
Effect of load on the shape of the slip surface and the velocity of the landslide on a mixture of clay sand
}

\author{
Julita Andrini Repadi ${ }^{*}$, Fathol Bari ${ }^{1}$, Junaidi, and Oscar Fitrah Nur ${ }^{1}$ \\ ${ }^{1}$ Departement of Civil Engineering, Faculty of Engineering, Andalas University, West Sumatera, Indonesia
}

\begin{abstract}
The slip surface has an essential role in slope stability analysis. The slip surface is to be known to calculate the safety factor. The velocity of landslides needs to be done to mitigate when a landslide occurs to reduce the risk. This study aims to determine the shape of the slip surface and the velocity of the landslide with variations in load and 2 combination material. The slope is formed in a glass box measuring $110 \times 10 \times 40$ $\mathrm{cm}$. The slope angle used is the same as the angle of internal friction. The slope is given a uniform load until the slope collapses. Loading is done by using a pressure device placed on the prooving ring at the bottom of the press. From both material variatn ions and load variations, it can be seen that the shape of the slip surface that occurs is almost the same, namely in the form of a slip surface. So it is concluded that the load does not affect the shape of the slip surface. The velocity that occurs in combination 1 is moderate-rapid, while combination 2 is moderate. Combination 2 clay is safer than combination 1 but not too significant.
\end{abstract}

\section{Introduction}

Landslides are known to occur on all continents, seas, and oceans. In many areas of the world, landslides are a serious threat. This has led to landslide modeling, and landslide risk evaluation becoming increasingly popular among scientists and practitioners. However, due to natural factors, landslides are difficult to predict, limiting the community's ability to reduce the risk of landslides [1].

Landslides with a high death toll are often the result of failures in land management. Based on BPS data in 2021, Indonesia's population continues to increase from 2018 to 2020 , the significant increase in population is $1 \%$ per year or more than 2.6 million per year. The increasing number of residents has resulted in people having to build houses in hilly and mountainous areas. According to BPS 2021 data, in Indonesia the number of victims who died and went missing in 2020 due to landslides was 124 people, injured 87 people, affected and displaced as many as 23,375 people. Of the 34 provinces in Indonesia, West Sumatra is in the 4 th position with the most deaths, 6th position with injuries and 11th position affected and displaced provinces.

According to the World Health Organization (WHO), the area most vulnerable to landslides is land that has changed due to human activities such as construction. The increase in population in Indonesia can trigger construction development, and construction development eventually triggers landslides.

Understanding the interrelationships between Earth's surface processes, ecological systems, land use, and human activities is key to reducing the risk of erosions.
Due to limited land, people are no longer worried about the dangers that occur due to landslides. According to Hakam (2019) research, people in the Sianok Canyon area are no longer concerned about the threat of landslides due to limited land. They live at very high risk [2].

Analysis of slope stability has a crucial role in the planning of civil constructions. Calculating the minimum factor of safety of a slope is very important in geotechnical engineering. Calculating the minimum slope safety factor or finding the slip surface of a hill is a complex problem[3]. Slope stability analysis is related to safety factors. To calculate the safety factor of the slope, it is necessary to know the shape of the slip surface.

The various types of slip surfaces are translation, rotation, block, rock debris, soil creep, and debris. Researchers who have researched the shape of the slip surface numerically are in rotation [4-11].

Landslides occur when the driving force is greater than the resisting force. The retaining force is generally influenced by the strength of the rock and the density of the soil, while the driving force is one of the causes due to the load of the building on it.

This research is present by looking at the effect of the load on the slope with a decrease in the slope of $1 \mathrm{~cm}$ and 2.5 to see its impact on the shape of the slip surface

\section{Slope Stability}

Landslides occur when the driving force exceeds the resisting force. The stability of this slope is quantified in terms of the Factor of Safety (FS), as shown in Equation 1. part of the landslide as shown in Fig. 1.

\footnotetext{
*Corresponding author: julitaandrinirepadi@gmail.com
} 


$$
\begin{aligned}
& \mathrm{SF}=\frac{\text { Resisting Force }}{\text { Driving Force }} \\
& \mathrm{SF}<\text { Slope is unstable } \\
& \mathrm{SF}>1 \text { Slope is stable }
\end{aligned}
$$

\begin{tabular}{|c|c|c|c|}
\hline $\begin{array}{l}\text { Velocitty } \\
\text { class }\end{array}$ & Description & $\begin{array}{l}\text { Velocity } \\
(\mathrm{mm} / \mathrm{s})\end{array}$ & $\begin{array}{l}\text { Probable } \\
\text { destructive } \\
\text { significance }\end{array}$ \\
\hline 7 & $\begin{array}{l}\text { Extremely } \\
\text { Rapid }\end{array}$ & $>5.10^{3}$ & $\begin{array}{l}\text { A major violent } \\
\text { disaster, buildings } \\
\text { destroyed due to } \\
\text { the impact of } \\
\text { abandoned } \\
\text { materials, many } \\
\text { deaths, society is } \\
\text { impossible to } \\
\text { escape. }\end{array}$ \\
\hline 6 & Very Rapid & $<5.10^{3}$ & $\begin{array}{l}\text { Several lives were } \\
\text { lost, the velocity } \\
\text { was too great to } \\
\text { support everyone } \\
\text { to save themselves }\end{array}$ \\
\hline 5 & Rapid & $<5.10^{1}$ & $\begin{array}{l}\text { Evacuation escape } \\
\text { possible, } \\
\text { structures, } \\
\text { property and } \\
\text { equipment } \\
\text { destroyed }\end{array}$ \\
\hline 4 & Moderate & $<5.10^{-1}$ & $\begin{array}{l}\text { Some temporary } \\
\text { and insensitive } \\
\text { structures can be } \\
\text { preserved. }\end{array}$ \\
\hline 3 & Slow & $<5.10-^{3}$ & $\begin{array}{l}\text { Construction } \\
\text { improvements can } \\
\text { be made. If } \\
\text { landslide } \\
\text { movement is not } \\
\text { large, } \\
\text { Construction can } \\
\text { be maintained } \\
\text { with frequent } \\
\text { maintenance. }\end{array}$ \\
\hline 2 & Very slow & $<5.10^{-5}$ & $\begin{array}{lr}\text { Landslide did not } \\
\text { damage some } \\
\text { permanent } \\
\text { buildings. }\end{array}$ \\
\hline 1 & $\begin{array}{l}\text { Extremely } \\
\text { Slow }\end{array}$ & $<5.10^{-7}$ & $\begin{array}{l}\text { Imperceptible } \\
\text { without } \\
\text { instruments, } \\
\text { construction } \\
\text { possible with } \\
\text { precautions }\end{array}$ \\
\hline
\end{tabular}

Table 1. Classification of landslides based on Cruden and Varnes [13]

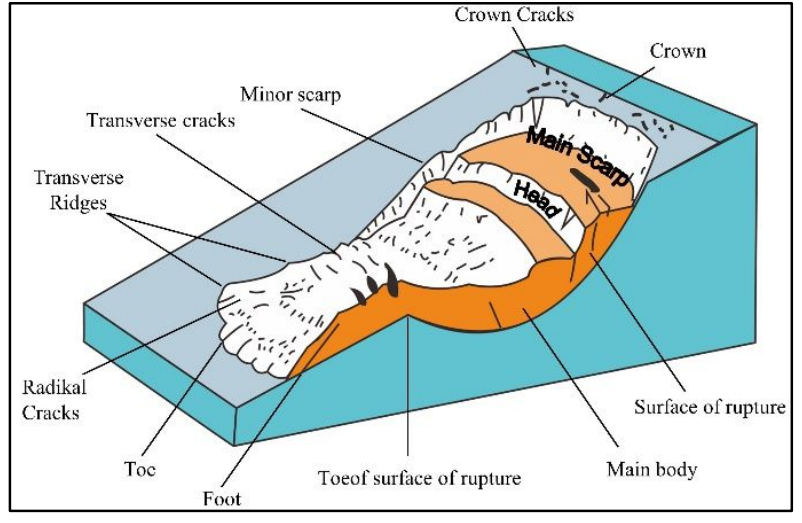

Fig 1. Part of the landslide

External Terzaghi classifies the occurrence of landslide into 2, namely external and internal factors, one of the causal factors is the load, in this study the cause of landslide. [12]

Understanding the interrelationships between Earth's surface processes, ecological systems, and land use, and human activities are key to reducing the risk of landslides. Knowing the velocity of landslides can also prevent and limit the number of human casualties and property damage. Landslide is the movement of rock, soil debris, etc., down a slope near the earth's surface due to the force of gravity. The rate of landslides can occur very slowly to very quickly down the slope, following the classification of slopes.[13]

\section{Methodology}

The steps taken in this research are as follows [14]:

1. Preparing material samples

The material used is fine sand, passed the no.10 sieve and was retained by the no. 200 sieve. The sand is first washed to remove the silt content and other organic matter, while the clay is dried to facilitate filtration with filter no. 200, Experiments were carried out with two combinations of materials, namely:

a. The first combination is $95 \%$ sand $+5 \%$ clay, as shown in Fig. 2

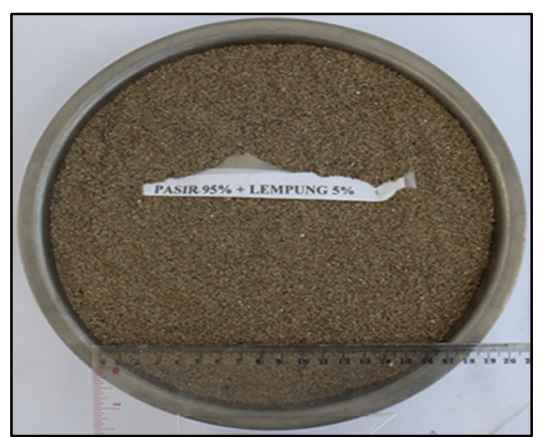

Fig. 2. Combination 1 ( $95 \%$ sand $+5 \%$ clay $)$ 
b. The second combination is $90 \%$ sand $+10 \%$ clay, as shown in Fig 3.

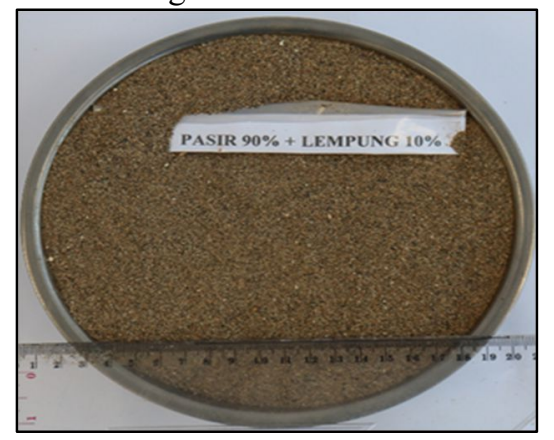

Fig. 3. Material mixture of sand $90 \%$ + clay $10 \%$

2. Preparing equipment

The equipment used is a glass box measuring $110 \mathrm{~cm}$ $\mathrm{x} 40 \mathrm{~cm} \times 10 \mathrm{~cm}$, iron cut with a length of $9.8 \mathrm{~cm}$ as a static load, plate $9.8 \times 21 \mathrm{~cm} \times 1 \mathrm{~cm}$, coloured markings, pressing tools, Proving rings,

3. The camera is mounted on a tripod placed in front of the slope and next to the slope.

4. Conducting soil parameter testing

Testing Total weight $(\gamma)$, cohesion (c), and Angle of Internal Friction $(\Phi)$, Soil density (Dr) and Water content (w), as shown in Table 2

Table 2. Soil Parameters

\begin{tabular}{|l|c|c|}
\hline & Combination 1 & Combination 2 \\
\hline $\begin{array}{l}\text { Total Weight } \\
(\mathrm{\gamma})\end{array}$ & $15,76 \mathrm{kN} / \mathrm{m}^{3}$ & $15,89 \mathrm{kN} / \mathrm{m}^{3}$ \\
\hline Cohesion (c) & $0,09 \mathrm{kN} / \mathrm{m}^{2}$ & $0,33 \mathrm{kN} / \mathrm{m}^{2}$ \\
\hline $\begin{array}{l}\text { Angle of } \\
\text { Internal } \\
\text { Friction }(\Phi)\end{array}$ & $35,06^{0}$ & $33,69^{0}$ \\
\hline $\begin{array}{l}\text { Soil Density } \\
(\text { Dr) }\end{array}$ & $73 \%$ & $70 \%$ \\
\hline $\begin{array}{l}\text { Water } \\
\text { Content }(\mathrm{w})\end{array}$ & $3,168 \%$ & $3,766 \%$ \\
\hline
\end{tabular}

5. Slope Making

Slopes are made with a slope angle equal to the shear angle in the slope. Then put a coloured mark $2.5 \mathrm{~cm}$ in the horizontal direction and $2.5 \mathrm{~cm}$ in the vertical direction.

6. Giving burden

7. Loading is done by arranging pieces of iron measuring $9.8 \mathrm{~cm}$ above the slope, then on top of the pieces of iron, a plate measuring $9.8 \mathrm{~cm} \times 21 \mathrm{~cm}, 1 \mathrm{~cm}$ thick, is placed under the pressing device, then the proving ring is pressed with pressure tool. The proving ring is used to see the value of the load, and the dial gauge is used to see the value of the decrease in slope.Seeing the shape of the slope collapse,

8. Processing load data, time, settlement, slope failure form, velocity.

9. Giving conclusion

\section{Analysis and Discussion}

The first combination ( $95 \%$ sand $+5 \%$ clay) was carried out 3 times. The shape of the slip surface is observed, as shown in Fig. 3 where the shape of the slip surface from 3 experiments with a load of $1 \mathrm{~cm}$ and $2.5 \mathrm{~cm}$, the shape of the slip surface is almost the same, namely rotation, so it can be concluded that the load does not affect the shape of the slip surface.

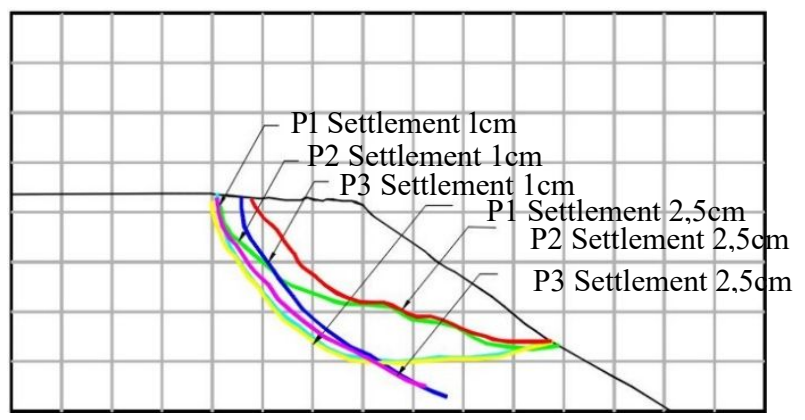

Fig. 3. Form of slip surface from the combination of $95 \%$ sand $+5 \%$ clay

Furthermore, the load, time, and velocity were observed with a decrease of $1 \mathrm{~cm}$ and $2.5 \mathrm{~cm}$. Experiment 1 are shown in Table 3, Experiment 2 is shown in Table 4, and Experiment 3 is shown in Table 5.

Table 3. Comparison of load, settlement, time, and velocity in experiment 1 material $95 \%$ sand $+5 \%$ clay

\begin{tabular}{|r|r|r|r|r|}
\hline Load(q) (ton/m2) & $\begin{array}{c}\text { Settlement } \\
\text { (cm) }\end{array}$ & $\begin{array}{c}\text { Time } \\
\text { (s) }\end{array}$ & $\begin{array}{c}\text { Velocity } \\
\text { (mm/s) }\end{array}$ & $\begin{array}{c}\text { Class } \\
\text { Velocity }\end{array}$ \\
\hline 0,00 & 0 & 0 & 0,000 & \\
\hline 4,56 & 1 & 29 & 0,345 & Moderate \\
\hline 9,41 & 2,5 & 65 & 0,385 & Moderate \\
\hline
\end{tabular}

Table 4. Comparison of load, settlement, time, and velocity in experiment 2 materials $95 \%$ sand $+5 \%$ clay

\begin{tabular}{|r|r|r|r|r|}
\hline Load(q) (ton/m2) & $\begin{array}{c}\text { Settlement } \\
\text { (cm) }\end{array}$ & $\begin{array}{c}\text { Time } \\
\text { (s) }\end{array}$ & $\begin{array}{c}\text { Velocity } \\
\text { (mm/s) }\end{array}$ & $\begin{array}{c}\text { Class } \\
\text { Velocity }\end{array}$ \\
\hline 0,00 & 0 & 0 & 0,000 & \\
\hline 4,56 & 1 & 36 & 0,278 & Moderate \\
\hline 2,14 & 2,5 & 50 & 0,500 & Rapid \\
\hline
\end{tabular}

Table 5. Comparison of load, descent, time and velocity in the 3 experiment materials $95 \%$ sand $+5 \%$ clay

\begin{tabular}{|r|r|r|r|l|}
\hline Load(q) (ton/m2) & $\begin{array}{c}\text { Settlement } \\
\text { (cm) }\end{array}$ & $\begin{array}{c}\text { Time } \\
\text { (s) }\end{array}$ & $\begin{array}{c}\text { Velocity } \\
\text { (mm/s) }\end{array}$ & $\begin{array}{c}\text { Class } \\
\text { Velocity }\end{array}$ \\
\hline 0,00 & 0 & 0 & 0,000 & \\
\hline 8,20 & 1 & 19 & 0,526 & Rapid \\
\hline 12,56 & 2,5 & 40 & 0,625 & Rapid \\
\hline
\end{tabular}

Table 6. Comparison of load, descent, time and velocity in the 3 experiment materials $95 \%$ sand $+5 \%$ clay

\begin{tabular}{|r|r|r|r|r|}
\hline $\begin{array}{c}\text { Load (q) } \\
\text { (ton/m2) }\end{array}$ & $\begin{array}{c}\text { Settlement } \\
(\mathbf{c m})\end{array}$ & Time $(\mathbf{s})$ & $\begin{array}{c}\text { Velocity } \\
(\mathbf{m m} / \mathbf{s})\end{array}$ & $\begin{array}{c}\text { Class } \\
\text { Velocity }\end{array}$ \\
\hline 0,00 & 0 & 0 & 0,000 & \\
\hline 5,77 & 1 & 28,00 & 0,38 & moderate \\
\hline 8,03 & 2,5 & 51,67 & 0,50 & moderate \\
\hline
\end{tabular}


From the 3 experiments, the average load and velocity were taken the results obtainec are as shown in Table 6

The results showed that with a combination of $95 \%$ sand $+5 \%$ clay, the velocity that occurred was between moderate and rapid. Landslide with Moderate class means that when a landslide occurs, some temporary and insensitive buildings can be maintained. Meanwhile, erosions with rapid velocity mean that evacuation is possible, property and equipment are destroyed. To take the average of 3 trials the velocity that occurs is moderate which means that if the landslide is not permanent the building can still be maintaned.

The shape of the slip surface was observed with a combination of $90 \%$ sand $+10 \%$ clay material. The slip surface that occurs with 3 trials with a decrease of $1 \mathrm{~cm}$ and $2.5 \mathrm{~cm}$ is rotational, as shown in Fig 4.

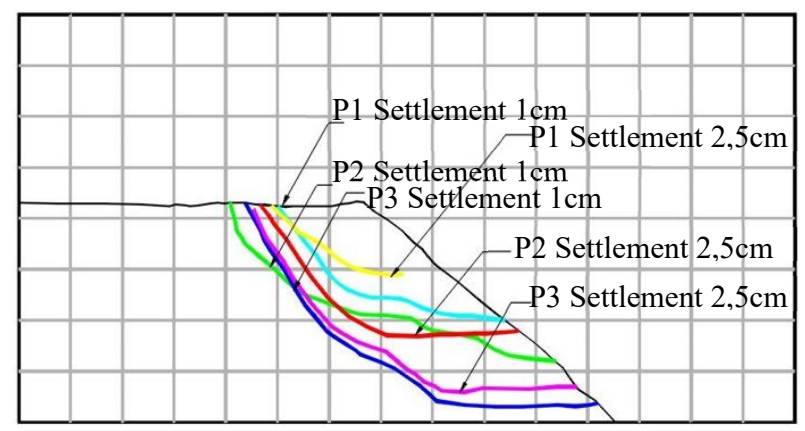

Fig. 4. Form of slip surface from the combination of $90 \%$ sand $+10 \%$ clay

The second combination ( $90 \%$ sand $+10 \%$ clay) was also tested 3 times. Observing the load, time and velocity that occurs, with a decrease of $1 \mathrm{~cm}$ and $2.5 \mathrm{~cm}$, the results are obtained as in Table 7, Table 8, and Table 9.

Table 7. Comparison of load, settlement, time and velocity in experiment 1 material $90 \%$ sand $+10 \%$ clay

\begin{tabular}{|r|r|r|r|r|}
\hline Load(q) (ton/m2) & $\begin{array}{c}\text { Settlement } \\
\text { (cm) }\end{array}$ & $\begin{array}{c}\text { Time } \\
\text { (s) }\end{array}$ & $\begin{array}{c}\text { Velocity } \\
\text { (mm/s) }\end{array}$ & $\begin{array}{c}\text { Class } \\
\text { Velocity }\end{array}$ \\
\hline 0,00 & 0 & 0 & 0,000 & \\
\hline 4,56 & 1 & 32 & 0,313 & Moderate \\
\hline 3,35 & 2,5 & 58 & 0,431 & Moderate \\
\hline
\end{tabular}

Table 8. Comparison of load, settlement, time and velocity in the experiment 2 materials $90 \%$ sand $+10 \%$ clay

\begin{tabular}{|r|r|r|r|r|}
\hline Load(q) (ton/m2) & $\begin{array}{c}\text { Settlement } \\
\text { (cm) }\end{array}$ & $\begin{array}{c}\text { Time } \\
\text { (s) }\end{array}$ & $\begin{array}{c}\text { Velocity } \\
\text { (mm/s) }\end{array}$ & $\begin{array}{c}\text { Class } \\
\text { Velocity }\end{array}$ \\
\hline 0,00 & 0 & 0 & 0,000 & \\
\hline 5,77 & 1 & 35 & 0,286 & Moderate \\
\hline 3,35 & 2,5 & 65 & 0,385 & Moderate \\
\hline
\end{tabular}

Table 9. Comparison of load, settlement, time and velocity in the experiment 2 materials $90 \%$ sand $+10 \%$ clay

\begin{tabular}{|r|r|r|r|r|}
\hline Load(q) (ton/m2) & $\begin{array}{c}\text { Settlement } \\
\text { (cm) }\end{array}$ & $\begin{array}{c}\text { Time } \\
\text { (s) }\end{array}$ & $\begin{array}{c}\text { Velocity } \\
\text { (mm/s) }\end{array}$ & $\begin{array}{c}\text { Class } \\
\text { Velocity }\end{array}$ \\
\hline 0,00 & 0 & 0 & 0,000 & \\
\hline 5,77 & 1 & 35 & 0,286 & Moderate \\
\hline 5,77 & 2,5 & 60 & 0,417 & Moderate \\
\hline
\end{tabular}

Table 10. Comparison of load, settlement, time and velocity in the experiment 2 materials $90 \%$ sand $+10 \%$ clay

\begin{tabular}{|r|r|r|r|r|}
\hline Load (q) (ton/m2) & $\begin{array}{c}\text { Settlement } \\
\text { (cm) }\end{array}$ & Time (s) & $\begin{array}{c}\text { Velocity } \\
\text { (mm/s) }\end{array}$ & $\begin{array}{c}\text { Class } \\
\text { Velocity }\end{array}$ \\
\hline 0,00 & 0 & 0 & 0,000 & \\
\hline 5,37 & 1 & 34,00 & 0,29 & moderate \\
\hline 4,16 & 2,5 & 61,00 & 0,41 & moderate \\
\hline
\end{tabular}

From Tables 7-10 it can be seen that the velocity that occurs is moderate, which means that some nonpermanent and insensitive structures can be temporarily maintained.

\section{Conclusion}

The shape of the slip surface from 3 trials for combination 1 (95\% sand $+5 \%$ clay) and combination $2(90 \%$ sand + $10 \%$ clay) with a load of $1 \mathrm{~cm}$ and $25 \mathrm{~cm}$ has the same shape, which is rotational, so it can be concluded that the load and variation 2 materials do not affect the shape of the slip surface.

The velocity that occurs from combination 1 compared to combination 2, combination 1 (95\% sand + $5 \%$ clay) has a greater velocity than combination $2(90 \%$ sand $+10 \%$ clay) which is in the moderate-rapid range in velocity class $4-5$, which means that some non-permanent and insensitive structures can be temporarily maintained and it is still possible for self-evacuation, but property and equipment are destroyed. If the average velocity class is taken, it is taken, it is class 4 moderate, while combination 2 is in the range of 4 which is moderate, some temporary and insensitive structures can be temporarily maintained, but between combination 1 and combination 2 there is no significant difference

\section{References}

1. I. Machdi, statistical year book of Indonesia, (BPSStatistics Indonesia, Jakarta, 2021)

2. A. Hakam, Slope stability and ground retaining wall, (Andalas University Press, Padang, 2010)

3. Li, S.H., Wu, L.Z. and Luo, X.H., A Novel Method for Locating the Critical Slip Surface of A Soil Slope, J. of Engineering Applications of Artificial Intelligence, 94, 2020, 1-15 (2020)

4. W. Fellenius, Calculation of the stability of earth dams, In Proceedings of the second congress of large dams, 4,. 445-463, Wash- ington DC (1936)

5. A. W. Bishop, The Use of the Slip Circle in the Stability Analysis of Slopes, Geotechnique, 5, pp. 7-17 (1955)

6. N. R. Morgenstern, V. E. Price, The Analisys of the Stability of General Slip Surfaces, The Institution of Civil Engineers, 79-93, London (1965)

7. E. Spencer, A Method of Analisys of the Stability of Embankments Assuming Parallel Inter-Slice Forces, Manchester University Institut of Science and Technology, 11-26, Inggris (1967) 
8. S. K. Sarma, ICE, 23, pp. 323-433, London (1973)

9. M. Jafri, Iswan, M. Rizki, G.E. Susilo, CIVENSE, 3, 1 (2020)

10. Raj D and Yogendra S. Effect of Building Loads on the Stability of Hill Slopes. ASCE. 638-647 (2016).

11. Janbu, N. Slope Stability Computations. Embankment Dam Engineering - Casagrande Volume, R.C. Hirschfeld and S.J. Poulos, eds., John Wiley and Sons, New York, 47-86 (1973).
12. Terzaghi K Mechanisms of landslides. Geological Society of America, Berkley, 83-123 (1950).

13. S. P. Pradhan, V. Vishal, T.N. Singh, Springer, 50 (2019).

14. J. Andrini Repadi, F. Bari, Junaidi, F. Anas Ismail, Andriani, A. Hakam, Slip surface in a clay-sand mixture slope test Using scaled laboratory models, International Journal of GEOMATE, Sept 2021, Japan (2021). 